Max-Planck-Institut für demografische Forschung

Max Planck Institute for Demographic Research

Konrad-Zuse-Strasse 1 - D-18057 Rostock - GERMANY

$\mathrm{Tel}+49$ (0) 3812081 - 0; Fax +49 (0) 3812081 - 202;

http://www.demogr.mpg.de

MPIDR WORKING PAPER WP 2009-011

APRIL 2009

\title{
Finding the "right moment" for the \\ first baby to come: A comparison \\ between Italy and Poland
}

Anna Matysiak (amatys@sgh.waw.pl)

Daniele Vignoli (vignoli@ds.unifi.it)

This working paper has been approved for release by: Gerda Ruth Neyer (neyer@demogr.mpg.de), Head of the Laboratory of Population and Policy.

(C) Copyright is held by the authors.

Working papers of the Max Planck Institute for Demographic Research receive only limited review. Views or opinions expressed in working papers are attributable to the authors and do not necessarily reflect those of the Institute. 


\title{
Finding the "right moment" for the first baby to come: A comparison between Italy and Poland
}

\author{
Anna Matysiak ${ }^{(1)}-$ Daniele Vignoli $^{(2)}$ \\ ${ }^{(1)}$ Institute of Statistics and Demography (Unit of Demography), Warsaw School of \\ Economics, amatys@sgh.waw.pl \\ (2) Dipartimento di Statistica “G. Parenti”, Università di Firenze, vignoli@ds.unifi.it
}

\begin{abstract}
This goal of this study is to add to our understanding of the impact of women's human capital accumulation on the timing of first births. Applying intensity regression to national retrospective data, we examined the transition to motherhood in Italy and Poland. These countries share several similarities - Catholicism, strong family ties, and considerable tensions between fertility and work - but also differ in female labor supply developments. Our life-course study illustrates that paid employment clearly discourages childbearing in Italy, at least among low- and medium-educated women. In Poland, by contrast, employment functions as a precondition to childbearing, irrespective of a woman's educational level.
\end{abstract}




\section{1 - Introduction}

More and more often young women educate themselves for lifelong professional careers. Increasingly some of them are delaying the decision to have a first child, while others are finding that there is no space for childbearing and childrearing over their life-course. Therefore, many commentators envision the changing status of women as one of the main driving forces behind the decline in fertility levels observed in all European societies (e.g., Frejka et al., 2008). In that context, the timing of first births plays a crucial role at least for two reasons. First, having a first child later in life may leave little time for second (or higher) order births (Frejka \& Sardon, 2007). Second, delaying the entry to motherhood may lead to childlessness (Sobotka, 2004, pp. 123-153).

Postponing first births affects fertility quantum, particularly in those societies that experienced strong increases in women's educational attainment, but in which the domestic institutions - such as labor market regulations, childcare provisions, and traditional couple role-sets - have not adjusted to the ongoing societal change (e.g., McDonald, 2000). Southern European countries and Central and Eastern Europe are clear examples of this state of affairs. In this study, we investigate the timing of first birth in these two areas of Europe, focusing on Italy and Poland. These two countries offer a stimulating, and so far unexplored setting for a comparative analysis.

On the one hand, Italy and Poland have enough in common to provide a valuable basis for comparison. They are both characterized by extremely low fertility (currently around 1.3). Many aspects of their cultures (religiosity, strong family relations, and fundamental importance of marriage) and institutions (underdeveloped public childcare, rigid labor markets, strong barriers to the labor market entry, limited access to social benefits, lack of housing subsidies, and high mortgage costs) may be seen as similar (e.g., De Rose et al., 2008; Kotowska et al., 2008).

On the other hand, these countries display enough key differences to make this comparison informative. Most importantly, the labor force participation of women aged 25 to 44 is much higher in Poland than in Italy, despite the strong time conflict between family and professional life prevailing in both countries. Furthermore, Polish first-time mothers are still much younger than their Italian counterparts, and the living standards of the young Poles are, on average, lower than those of the Italians.

The comparison of these two similar countries can facilitate our understanding of how the country-specific differences mediate the influence of women's increasing investments in 
human capital on the decision to have the first child. More specifically, we explore the impact of women's educational attainment and accumulated work experience on the transition to motherhood.

The paper is organized as follows. In the next section we present our theoretical framework. Section 3 provides background information on the demographic and socioeconomic settings in Italy and Poland. In Section 4 we formulate our research hypotheses, which are derived from our theoretical premises and the country context descriptions. The analytical strategy of the study is presented in Section 5, and is followed by a description of the empirical findings in Section 6. In the concluding Section 7 we discuss our results and their implications.

\section{2 - Theoretical perspectives on the postponement of a first birth}

Most European societies have experienced shifts in first birth timing toward the older ages. In many of these countries, the incidence of childlessness has also increased. Here we provide a framework which combines the three main driving forces behind the postponement, as identified by Billari et al. (2006): (a) the pivotal importance of increasing female human capital accumulation, (b) the potential role played by the ideational shift, and (c) the impending impact of rising uncertainty in the globalizing world.

There is general agreement among scholars that one of the major forces behind the postponement of childbearing is the change in the social roles of women (e.g., Blossfeld \& Huinink, 1991; McDonald, 2000). The increasing desire of women to invest in their human capital, together with an almost perfect control over their fertility, led to the situation in which the decision about the timing of the first birth is an outcome of a rational decision-making process. In this theoretical framework, finding the right time to conceive the first child requires an evaluation of the costs and benefits related to childbearing, both in the short- and the long-term.

Apart from the direct costs (financial expenditures), having a child also involves indirect costs. These include not only the income lost during the non-participation period, but also future earnings foregone due to non-accumulation and depreciation of human capital (Walker, 1995; Gustafsson, 2001). It has been widely argued in the literature that women who have their children early in life are more vulnerable to the negative impact of career interruptions on their wages than those who delayed motherhood, and instead accumulated 
some work experience (e.g., Hotz et al., 1997; Taniguchi, 1999). Thus women may tend to defer entry into motherhood, choosing instead to invest in their human capital first in order to maximize their life-time earnings. Furthermore, they might be interested in laying more general foundations for their careers through the achievement of a higher degree of security (such as obtaining a permanent contract or entitlement to social security provisions), or the fulfillment of self-realization needs (attaining promotion and reaching a certain professional status), which constitute additional costs of early childbearing (e.g., Ranson, 1998; McDonald, 2001; Låppegard \& Rønsen, 2005; Zabel, 2006). The motivation to postpone fertility is stronger when these costs are higher. In other words, the higher the human capital depreciation rate, the steeper the income profile or the promotion ladder, and the more uncertain the employment prospects, the more likely women are to delay childbearing (Gustafsson, 2001; Cigno \& Ermisch, 1989; Ermisch, 1990). Indeed, it has been widely documented in the literature that the first birth risk rises as the time since leaving education passes (Kantorová, 2004; Nicoletti \& Tanturri, 2008), and as women accumulate work experience (Kravdal 1994) and attain more stable positions in the workplace (Happel at el. 1984).

Within this framework, the postponement of births observed in recent years could be explained by an increase in the costs of early childbearing. This increase could have taken place for at least three reasons. First, the modernization processes led to a change in the value system, which was manifested in increased autonomy and a rising desire for self-fulfillment (Inglehart, 1990; Lesthaeghe, 1992; Surkyn \& Lesthaeghe, 2004). Second, globalization led to an expansion of choices and opportunities for a professional career, opening up new options for satisfying the higher order needs. Third, the same processes resulted in greater competition in the markets, and, consequently, in higher employment instability and income insecurity (Salvini \& Ferro, 2007; Mills \& Blossfeld, 2005; Kotowska, 2005).

The magnitude of the indirect costs related to early motherhood depends on the country-specific institutional and socio-cultural contexts, such as the educational system, labor market regulations, the childcare system, and gender relationships (Gustafsson \& Wetzels, 2001; Mills et al., 2005; Rindfuss et al., 2004). These costs are larger in countries with rigid labor markets and a pronounced insider-outsider divide, as well as in countries that lack safety nets and family policies oriented toward supporting the successful reconciliation of motherhood and paid work (Esping-Anderson 1999; Matysiak \& Vignoli, 2008, 2009). Thus, women in these countries may be more likely to defer childbearing out of a fear of being forced to take a prolonged career break than in countries where the incompatibilities 
between fertility and paid employment are weak. In our investigation, we focus on one country of Southern Europe (Italy), and one country of Central and Eastern Europe (Poland), in which institutional arrangements, as well as traditional norms for gender roles, make it problematic for women to combine work and family life.

\section{3 - Delaying motherhood in Italy and Poland: context review}

\subsection{Catholicism and strong family ties}

Italy and Poland represent a yet unexplored area for comparison. There are strong similarities between these two societies that set them apart from much of the rest of Europe, including the still low rates of cohabitation, non-marital childbearing, and marital disruption (Hantrais, 2005). The delayed diffusion of new family behaviors is often linked to the pressure imposed by Catholic principles (De Rose et al., 2008; Kotowska et al., 2008). Catholicism is perhaps the most significant element which unites Italy and Poland (e.g., Dalla Zuanna, 2004; Mariański, 2007). Only recently have the countries started to experience a slight weakening of ties with the Church, a process which is particularly visible among the younger generations, and is manifested in an increase in separation and divorce (Vignoli \& Ferro, 2008), as well as in cohabitation (Rosina \& Fraboni, 2004).

Additionally, both societies are characterized by strong attachment to the family and strong intergenerational ties (Dalla Zuanna \& Micheli, 2004; Rai et al., 2008; Stankuniene \& Maslaukaite, 2008). Parents support their children after the latter leave the parental home by helping them to establish an independent household, organizing a marriage ceremony, and later providing care for their children. In turn, they receive financial and emotional support in their old age (De Rose et al., 2008).

\section{2 - Delayed transition to motherhood}

Despite the strong position of the Catholic Church, the high degree of attachment to the family, and the prevalence of traditional family forms, Italy and Poland have experienced a marked decline in childbearing, and currently belong to the countries with the lowest fertility levels in Europe. Younger generations increasingly opt for late entry to parenthood, and the proportion of the childless has increased substantially in both of these societies. 
The decline in the first birth period total fertility rate (PTFR1) started first in Italy (Figure 1a). The PTFR1 had declined precipitously to 0.66 by the end of the $20^{\text {th }}$ century, after reaching a maximum in 1964 of 1.02 first births per woman. In Poland the downward trend started around two decades later, but its intensity was even stronger (particularly after 1989). The PTFR1 dropped from 0.93 in the mid-1980s, to its lowest point of 0.57 in 2002. Only in recent years has an increase in first birth rates been recorded. This trend started first in Italy, in 1998, and, with a time lag of five years, was also observed in Poland.

The decline in the period first birth rate is largely an effect of postponing the entry into motherhood. In fact, the mean age at first delivery in Italy increased from 25 in the early 1970 s, to 29 in 2007. In Poland, the mean age at first birth rose from 23.3 in 1989 to 25.8 in 2007. In recent years, however, both countries have experienced a relatively large increase in childlessness (Frejka, 2008). In Italy the proportion of women who remained childless rose from 10\% among the 1955 cohort, to $20 \%$ among the 1965 cohort (Figure 1b). In Poland this process started slightly later, with the percentage of women who had no children jumping five percentage points from 1960 to 1965 cohort, to $15.4 \%$ for the latter cohort.

Although we do not know the completed fertility of the younger cohorts, analyzing their age patterns at the entry into motherhood might give us greater insight into the postponement process. Figures $2 \mathrm{a}-\mathrm{b}$ illustrate the cohort first birth age-specific fertility rates. Note that the data series for Italy are shorter than for Poland because of the data limitations.

In Italy, the postponement is observed starting with the cohorts born in the mid-1960s. Figure 2 a clearly shows the decline in the first birth rates at ages 20-25, and an increase thereafter. This suggests that women began to adopt a "diachronic strategy," which is "characterized by a postponement, and then a recovery of childbearing" (Caltabiano et al., 2006). In Poland, the process of postponement started later, with cohorts born in the 1970s (Figure $2 b$ ). The time when the majority of first births were delivered before the age of 23 has gradually passed. From the cohorts born in the 1980s onwards, women began to enter motherhood predominantly in the second half of their twenties. 
Figure 1 - (a) First birth total period fertility rate (PTFR1), 1960-2004 for Italy, and 19792007 for Poland. (b) First birth total cohort fertility rate (CTFR1), birth cohorts 1922-1967 for Italy, and 1938-1967 for Poland.

a)

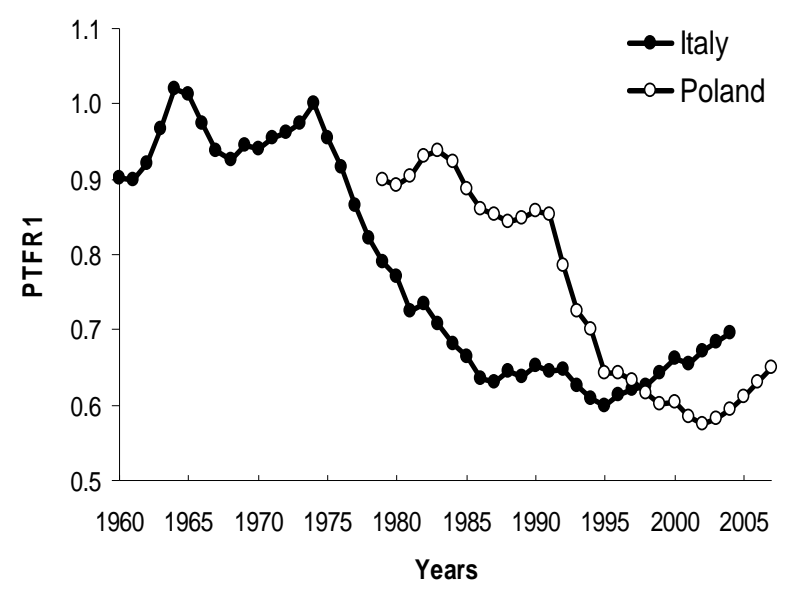

b)

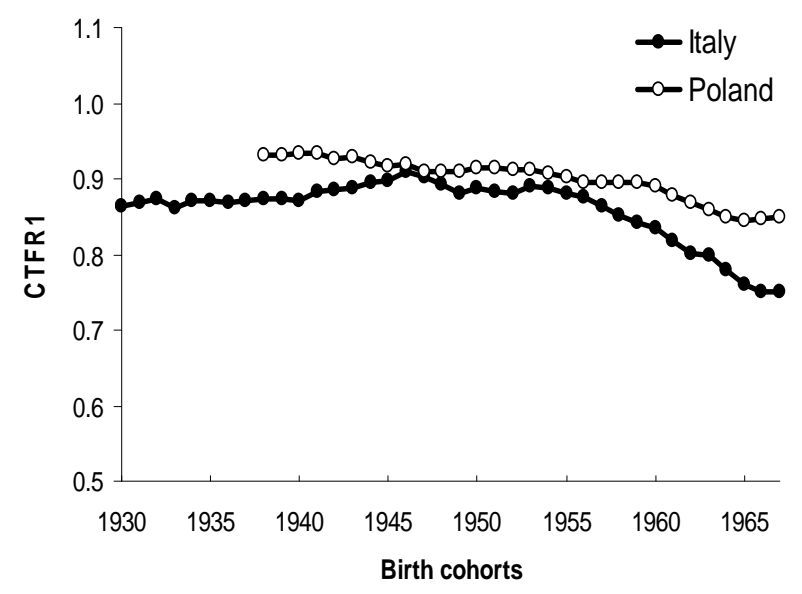

Source: Observatoire Démographique Européen. The data for Italy for the generations 1960-1967 are provided in De Rose et al. (2008). The indicators for Poland for the years 2004-2007 are computed by Krzystof Tymicki based on the Polish Birth Register.

Figure 2 - First birth age-specific fertility rates. (a) Birth cohorts 1950, 1960, 1965, 1970, 1975, and 1980, Italy. (b) Birth cohorts 1960, 1965, 1970, 1975, 1980, and 1985, Poland.

a) Italy

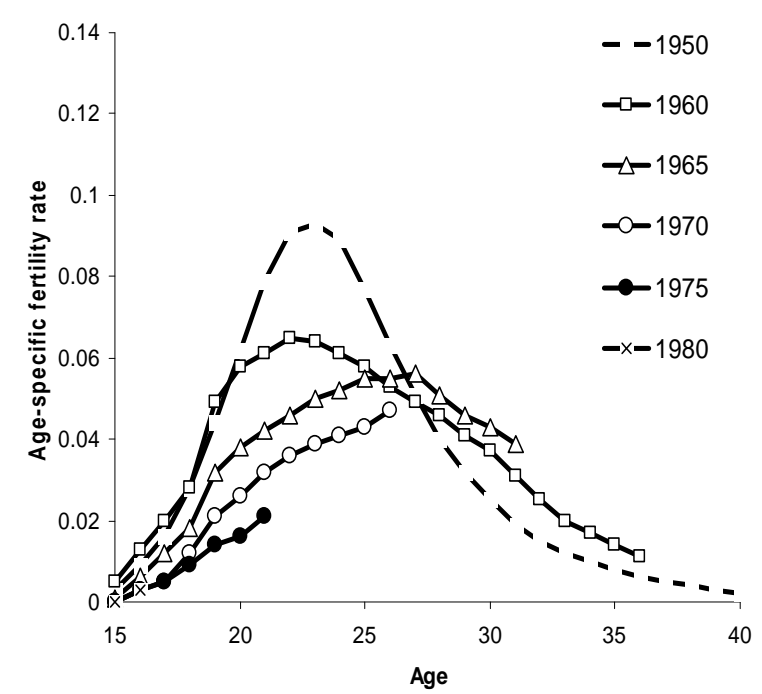

b) Poland

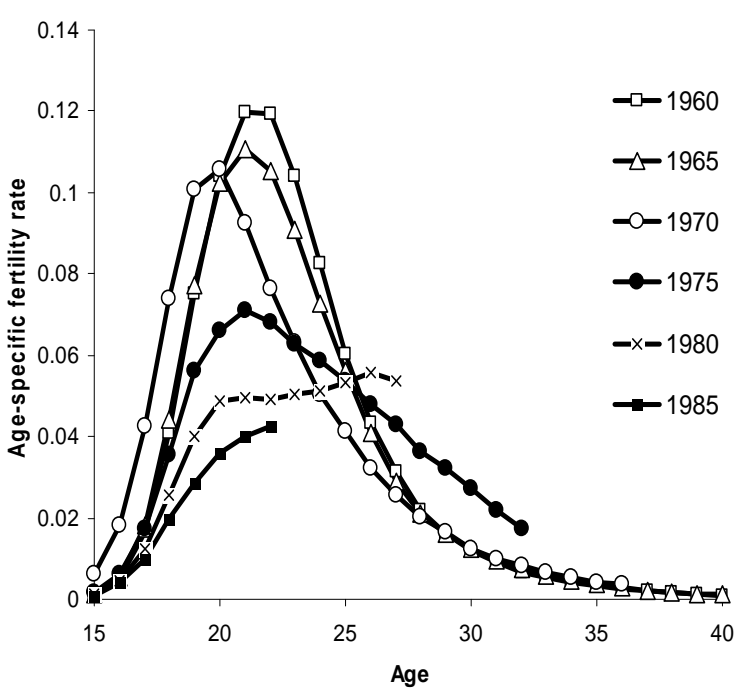

Source: Observatoire Démographique Européen; the indicators for Poland for the years 2004-2007 are computed by Krzystof Tymicki based on the Polish Birth Register. 
This massive fertility postponement in Italy and Poland is often explained in the literature by the emergence of social and economic changes that have not been accompanied by the adjustment of the institutional framework (Livi-Bacci, 2001; De Rose et al., 2008; Kotowska, 1999; Kotowska et al., 2008; Kertzer et al., 2008). In Italy this change has been taking place since the 1970s. It was manifested in the development of the service sector, the rising educational attainment of women, and the increasing participation of women in the labor force. The pace of these processes was more gradual than in Poland, however. In the latter country, the social and economic change started in 1989 and progressed much more rapidly, largely affecting the childbearing behaviors of women born in the 1970s or later. This sudden shift was closely related to the economic and political transformation that followed the collapse of state socialism. The new capitalist system, based on Western principles, replaced the centrally planned economy. Employment became no longer guaranteed, job security ceased, public childcare underwent deterioration, and the importance of education for earning income and achieving personal success increased substantially. This resulted in a remarkable rise in educational attainment among the Poles, as well as in a considerable intensification of the incompatibilities between paid work and family life. For Polish women, most of whom were already economically active during the period of state socialism, competing in the labor market became much more difficult than in the past.

\section{3 - Strong incompatibilities between fertility and paid employment}

In neither of the analyzed countries have labor market and family policies adjusted to the ongoing developments. Work arrangements have remained rigid, and the barriers to entry in the labor market are still very high (Matysiak, 2008, pp. 96-97). Women are polarized between full-time employment and non-employment. This problem is particularly severe in Poland, where less than $10 \%$ of women aged 25-49 work part-time (Table 1). Both countries are also characterized by high employment protection of insiders, which particularly affects the (re-)employment prospects of young people and mothers. As a result, Italy and Poland have exceptionally high unemployment rates among young people (Table 1). The disadvantaged position of women in the Italian labor market is additionally reflected in high gender unemployment gap (Adsera, 2005). 
Table 1. Contextual indicators, Italy and Poland

\begin{tabular}{|c|c|c|}
\hline & ITALY & POLAND \\
\hline \multicolumn{3}{|l|}{ Labor market structures $^{\text {a) }}$} \\
\hline \% part-time employed (aged 25-49 in 2006) & 27.9 & 9.3 \\
\hline youth unemployment in 2006 & 21.6 & 29.8 \\
\hline $\begin{array}{l}\text { gender unemployment gap in } 2006 \text { (female - male } \\
\text { unemployment rate) }\end{array}$ & 3.4 & 1.9 \\
\hline$\%$ temporarily employed (aged $15-24$ in 2006) & 38.0 & 59.0 \\
\hline$\%$ temporarily employed (aged $25-49$ in 2006 ) & 15.3 & 22.7 \\
\hline \multicolumn{3}{|l|}{ Childcare provision $^{\text {b) }}$} \\
\hline children aged $0-2$ & $7.4 \%$ & $2.4 \%$ \\
\hline children aged 3-6 & $95 \%$ & $61.9 \%$ \\
\hline \multicolumn{3}{|l|}{ Parental leave $^{c)}$} \\
\hline duration & 6 months & 36 months \\
\hline benefit & $\begin{array}{l}30 \% \text { of monthly } \\
\text { earnings in private } \\
\text { sector, and } 80-100 \% \\
\text { in public sector }\end{array}$ & $\begin{array}{l}\text { means-tested, flat rate } \\
\text { at the around } 15 \% \text { of } \\
\text { the average wage in } \\
\text { the national economy }\end{array}$ \\
\hline $\begin{array}{l}\text { Proportion of working mothers with children up to } \\
\text { age } 14 \text { who receive childcare support from kin }{ }^{\text {d) }}\end{array}$ & $40 \%$ & $42 \%$ \\
\hline
\end{tabular}

Source: ${ }^{\text {a) }}$ - Eurostat New Cronos Database (Labor Force Survey data), ${ }^{\text {b), c) }}$ - Italy: Neyer (2003) and De Rose et al. (2008), Poland: Matysiak (2008, pp. 156-157), d) - Eurostat New Cronos Database (data from the "Reconciliation between work and family" survey 2005).

In addition, public childcare provision is very weak in the two countries (with the exception of arrangements for pre-schoolers in Italy), largely due to the underlying belief that childcare is a private issue that should be handled within the family (Table 1). Women can, however, make use of maternity and parental leave entitlements, which are offered to all working mothers irrespective of their work record. Parental leaves are particularly long in Poland, though in the majority of cases they are unpaid (Table 1). For those mothers who decide to work, the family constitutes an important support in providing childcare.

Finally, the attitudes toward working mothers in both analyzed countries are very traditional, and the gender division of tasks is heavily asymmetric (e.g., Lück \& Hoffäcker, 2003; Mencarini \& Tanturri, 2006; Muszyńska, 2007; Philipov, 2008). The view that women 
should withdraw from the labor market when their children are young also prevails in Poland, despite the fact that the state ideology strongly encouraged the labor force participation of women during the socialist period. Even during that era, women were perceived to be the main homemakers and care providers (Siemieńska, 1997).

This institutional, structural, and cultural lags have led to strong tensions between fertility and paid work. These tensions may discourage women from having children if they plan to be economically active. Additionally, the arising incompatibilities between motherhood and paid employment have recently been accentuated by the increasing uncertainty and instability of employment contracts. In fact, Italy and Poland belong to the group of countries with the highest proportion of employees on temporary contracts, exceeding 35\% among young people aged 15-24, and 15\% among those aged 25-49 (Table 1).

\subsection{Different developments in female labor supply}

Despite the strong incompatibilities between fertility and women's work, both countries differ substantially in the current level of female labor force participation. Even larger differences emerge when past developments in women's economic activity are analyzed.

Italy has been always described as a country of low economic activity among women. Currently the labor force participation rate of females aged 25-44 stands at $67 \%$, which is around 10 percentage points less than the EU average. It is notable, however, that in the early 1970s the proportion of women in the labor force was twice as low, which points to a considerable increase. Single-earner, male-breadwinner couples are still seen as the most suitable environment for childbearing and childrearing in Italy. Women who intend to have a child are very likely to leave the labor market (Vignoli, 2008, p. 92), and those who give birth while in employment often do not return to work until the child grows older (Table 2).

The economic activity of women in Poland was already high in the 1960s, when over $60 \%$ of women aged 25-44 participated in the labor force. By the end of the 1980s, nearly $80 \%$ of Polish women were working (Table 2 ). This high economic activity among women was the result of the labor-intensive economy, low productivity, and low wage policies, as well as the communist ideology aimed at achieving full employment. The incompatibilities between paid work and childbearing were generally low at that time, thanks to the strong job guarantees, the right-to-a-job ideology, and public childcare provision. Interestingly, young women did not reduce their economic activity after the collapse of state socialism, despite the 
fact that the conditions of labor force participation changed dramatically, and it became much more difficult to combine paid work with family responsibilities. The strong orientation of women toward entering into employment and remaining employed was found in several studies (Matysiak, 2007; Matysiak \& Steinmetz, 2008). Recently, it has been additionally shown that having a job constitutes an important pre-requisite for childbearing in Poland (Matysiak, 2008, p. 188). Finally, Polish mothers tend to resume economic activity after their child reaches school age to a much larger extent than Italian mothers (Table 2).

Table 2. Labor market indicators, Italy and Poland

\begin{tabular}{|c|c|c|}
\hline & ITALY & POLAND \\
\hline \multicolumn{3}{|c|}{ Labor force participation of women aged $25-44^{\text {a) }}$} \\
\hline 1960 & 27.8 & 65.2 \\
\hline 1970 & 30.5 & 78.3 \\
\hline $1980(1978)$ & 45.0 & 79.2 \\
\hline $1990(1992)$ & 60.2 & 80.2 \\
\hline 2000 & 62.4 & 79.8 \\
\hline 2006 & 67.0 & 79.3 \\
\hline \multicolumn{3}{|c|}{ Labor force participation rate of women aged $25-40$ by the age of the youngest child in 2004} \\
\hline no children & 78.1 & 87.2 \\
\hline youngest child aged $0-4$ & 58.0 & 62.2 \\
\hline youngest child aged 5-9 & 58.2 & 83.1 \\
\hline \multicolumn{3}{|c|}{ Unemployment rate by education (women aged 25-49) in $2006^{c)}$} \\
\hline tertiary & 7.0 & 5.8 \\
\hline lower-secondary & 12.1 & 30.6 \\
\hline \multicolumn{3}{|c|}{ \% temporarily employed, by education (women aged 25-39) in $2006^{c)}$} \\
\hline tertiary & 20.6 & 18.8 \\
\hline lower-secondary & 14.3 & 31.2 \\
\hline
\end{tabular}

Source: ${ }^{\text {a) }}$ - ILO Laborsta Database, ${ }^{\text {b) }}$ - European Labor Force Survey (computations by Matysiak 2008, p. 45), c) - Eurostat New Cronos Database (Labor Force Survey data).

Determined to remain active in the labor market, women in Poland have greatly increased their participation in tertiary education (Sztanderska, 2005). The rationale behind this strategy lies in the protective character of education against job loss (Kotowska \& Sztanderska, 2007: 35). For example, in 2006 women with university degrees were five times less likely to experience unemployment, and almost twice as likely to have a fixed-term job, 
than women with lower-secondary education. The protective character of education is another country-specific feature that distinguishes Poland from Italy. In the latter country, females with a university degree are only slightly less exposed to unemployment, and tend to hold temporary contracts more often than the less-educated (Table 2).

\section{4 - Research hypotheses}

Based on the theoretical considerations and the context review outlined above, we formulate a set of hypotheses regarding the impact of women's human capital on the entry into motherhood in Italy and Poland.

First, we argue that fertility ageing observed in both societies is largely caused by the increasing investment of women in their human capital, as manifested in the rising educational attainment and accumulation of work experience over time.

Second, we expect some groups of women to be particularly likely to delay the entry into motherhood. These are women who have just started their careers, and need to establish their position in the labor market. The postponement strategy may also be more often implemented by women with higher levels of education who display a stronger orientation toward having a professional career, and who are most likely to experience promotion and advancement in salary. They may tend to defer childbearing particularly at the beginning of their careers, or during periods of increased uncertainty, when fulfilling the desire to participate in the labor force might be more difficult.

Furthermore, we also expect some differences between the two countries resulting from the different attitudes of women toward labor force participation. In particular, we anticipate that, after a period of stable employment, women in Poland will be more likely to decide to have a child than in Italy. This is due to the fact that, in Polish society, a woman's employment constitutes a pre-requisite, rather than an impediment, to childbearing; while the opposite tends to be the case in Italy.

Finally, the behavior of Polish women with a university degree may differ from that of Italian women due to the protective character of education against job loss in the former society. Polish women with tertiary education may establish their position in the labor market much more quickly than highly educated women in Italy, and may therefore progress to motherhood with much higher intensity. 


\section{5 - Analytical Strategy}

In investigating our research hypotheses, we have consulted two recent retrospective surveys: the Household Multipurpose Survey Family and Social Subjects (FSS), which corresponds to the Italian Generations and Gender Survey, and the Polish Employment, Family and Education Survey (EFES). The Italian survey was conducted by the Italian National Statistical Office (Istat) in November 2003 on a sample of about 24,000 households and 49,451 individuals of all ages. The Polish survey was prepared at the Institute of Statistics and Demography of the Warsaw School of Economics, and was conducted in November and December 2006. Around 3,000 women born between 1966 and 1981 participated in the Polish survey.

In our study we focus only on women. We could not adopt a couple perspective given the data limitations. We follow each woman from the age of 15 until the first conception (measured seven months before the first birth) or the date of the interview, whichever comes first. Although the Polish survey was conducted three years after the Italian one, we do not censor the Polish women in 2003. The rationale behind this choice is that fertility postponement in Poland started only recently, thus the years 2004-2006 can provide us with valuable information.

We are interested in comparing Italy and Poland after the onset of fertility postponement. For this reason, for Poland we select the cohorts born between 1970 and 1981 . These women were 8 to 19 in 1989, which means that they started their reproductive careers largely under the new political and economic conditions (see also Figure 2b). Taking the same cohorts for Italy as for Poland would mean following the Italian women for a period that is three years shorter than the period for Poland. For this reason, we chose for Italy cohorts born in the years 1967-1978. As a result, in both cases the analyzed women are aged 25-40 at the time of the interview. The Polish final sample includes 2,300 respondents (i.e., cohorts 19701981), while the Italian sample includes 4,238 respondents (i.e., cohorts 1967-1978).

With the goal of modeling the transition to first birth, we apply hazard regression specified as follows: 


$$
\begin{aligned}
\ln (h(t)) & =\sum_{i} \alpha_{1 i} \cdot A_{i}(t)+\sum_{j} \alpha_{2 j} \cdot T_{j}(t)+\sum_{k} \alpha_{3 k} \cdot E_{k}\left(t-t_{e}\right) \cdot e(t)+\sum_{l} \alpha_{4 l} \cdot W_{l}\left(t-t_{w}\right)+ \\
& +\alpha_{5} \cdot n e(t)+\sum_{s} \alpha_{6 s} \cdot s b_{s}
\end{aligned}
$$

where $\ln (h(t))$ is the log-hazard of first conception at time $t$. For simplicity, the subscripts for the individuals are suppressed. The log-hazard of first conception is composed of multiple clocks of duration dependence, each represented by a piecewise linear spline function of time. Piecewise linear splines are used to approximate continuous functions. They are functions which are linear within an a priori defined interval. With sufficient bend points, this specification allows us to capture efficiently any log-hazard pattern in the data (Lillard, 1993). The considered linear functions are: the time since the age 15, $A(t)$, calendar time, $T(t)$, and time since finishing education, $E\left(t-t_{e}\right)$, kicking in at $t_{e}$. The latter spline variable is interacted with the education level, $e(t)$. Additionally, for persons in employment, the $\log$ hazard of conception is constructed using the accumulated work experience, $W\left(t-t_{w}\right)$. This spline kicks in at the entry to work, $t_{w}$, and switches off when the person exits employment. The non-employment spells of the second or higher order are captured by the time-varying covariate $n e(t)$. In this way, we account for the effects of any possible job losses. The first non-employment spells refer to the state prior to entering any employment, and constitute the reference category for $W\left(t-t_{w}\right)$ and $n e(t)$. In the following section we refer to this state using the term 'never-worked'. Finally, we control for the respondent's social background, $s b^{s}$, by introducing each parent's education into the model. The $i, j, k, l$ represent the time intervals between the a priori specified bend points, while $s$ indexes the categorical variable $s b$.

In the second step, we interact work-experience and the variable ne(t), denoting nonemployment of second and higher order with the woman's education level, with the aim of gaining deeper insights into the impact of human capital on first birth risk. As a result, the formula (1) takes the following form:

$$
\begin{aligned}
\ln (h(t)) & =\sum_{i} \alpha_{1 i} \cdot A_{i}(t)+\sum_{j} \alpha_{2 j} \cdot T_{j}(t)+\sum_{l} \alpha_{4 l} \cdot W_{l}\left(t-t_{w}\right) \cdot e(t)+ \\
& +\sum_{m} \alpha_{5 m} \cdot n e(t) \cdot e(t)+\sum_{s} \alpha_{6 s} \cdot s b_{s}
\end{aligned}
$$


where subscript $m$ indexes the interaction between $n e(t)$ and $e(t)$. Note that the time since finishing education is not present in the Equation (2) because it partly captures the same phenomenon as the work experience interacted with education level.

Thanks to the fact that both surveys we use cover the full partnership, fertility, and employment histories of individuals, we could include in our model a whole set of timevarying covariates. Whereas the Polish survey also includes full education histories, the Italian one unfortunately provides information only on the date of the highest education level achieved. To address this problem, we assumed that the person is in school during the time prior to the date upon which the highest education level was attained. This assumption is justified by the still high degree of rigidity of Italian life-courses.

The women who had finished their education were classified into three groups: lowersecondary, upper-secondary, and tertiary. The first category comprises women who completed only compulsory education (eight years in both countries), as well as those who continued with basic vocational education, lasting three years in Italy and two years in Poland. The upper-secondary educated are those who completed at least four years of education at the upper-secondary level, as well as those who undertook post-secondary but non-tertiary education. Women who received a bachelor's or a master's degree are classified as tertiary educated.

\section{6 - Postponement of first birth in Italy and Poland: empirical findings}

We now present selected outcomes of our models. All estimates, produced within a step-wise procedure, are shown in the Appendix to the paper. We start our discussion from the estimates of the model specified by Equation 1 (Section 5).

The decline in first birth rates that was observed in Italy and Poland over recent decades is perfectly reflected in Figure $3(a-b)$. Note, however, that the decline is less pronounced after we take into account the changes in the status of women in the society, namely, after we control for women's social background, their educational attainment, and participation in paid employment. This means that the observed change in first birth rates results partly from an increase in the number of women joining higher social population strata. Nevertheless, even after accounting for this socio-economic compositional change, the overall decline in first birth risk remains substantial. This implies that our results only partly 
support the hypothesis that fertility ageing is largely driven by the increasing investment of women in their human capital, and suggests that fertility postponement is also caused by other factors.

Figure 3 - Temporal change in the first birth risk due to compositional change, attributable to parents' education, educational attainment, work experience.

a) Italy

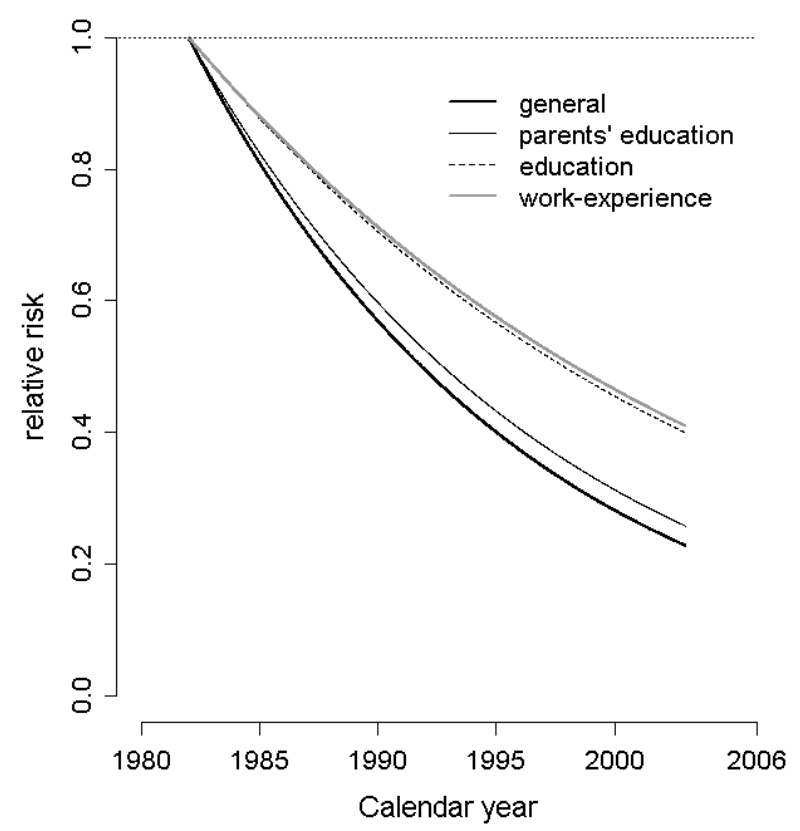

b) Poland

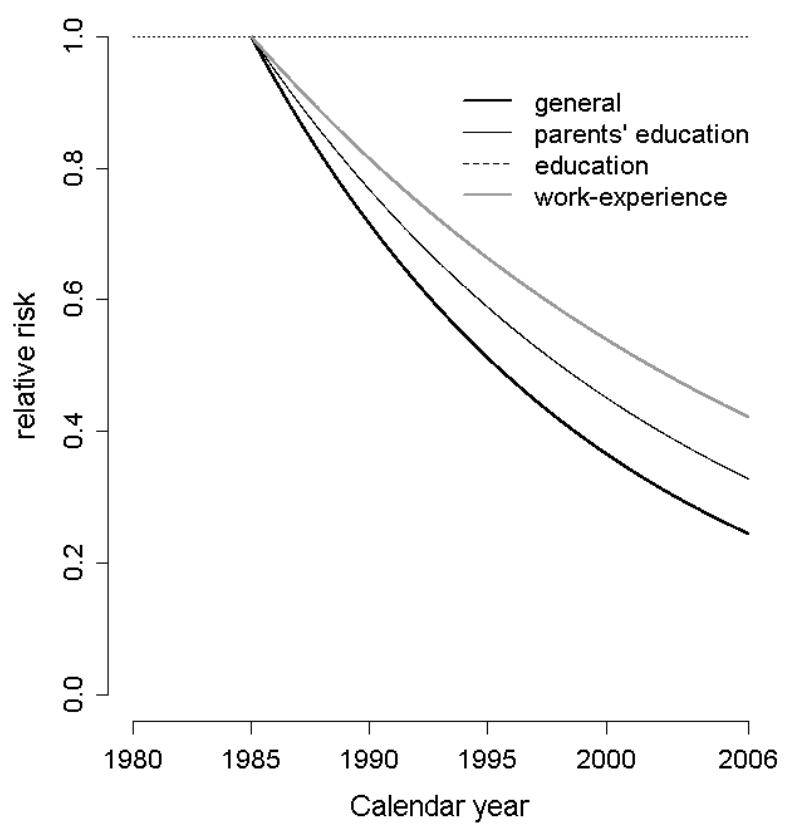

Note: The results come from the step-wise estimation of the model as presented in Equation 1.

Our findings clearly illustrate that the first birth risk differs both according to the level of education, and to the time elapsed since completing education (Figure 4a-b). The lowersecondary educated have the highest risk of having their first child upon leaving school, as well as over the whole period after completing education. At the other extreme we find the tertiary educated, while the upper-secondary educated lie almost in-between. Note, however, that the effects of finishing education on the first birth risk are much greater in magnitude in Italy than in Poland. This means that the end of education is a crucial step in the life-course of Italian women, who postpone entry into motherhood until they complete their education. In 
Poland, finishing education is also important. Nonetheless, Polish women still seem to be more likely than Italian women to conceive their first child while still enrolled in education.

The study provides support for our hypothesis that tertiary educated women are most likely to delay entry into motherhood after graduation. In addition, most do not decide to have a child soon after earning a degree, in contrast to the less educated. This is consistent with the view that women with higher human capital seek to lay more general foundations for their careers.

Figure 4 Effect of education on first birth risk

a) Italy

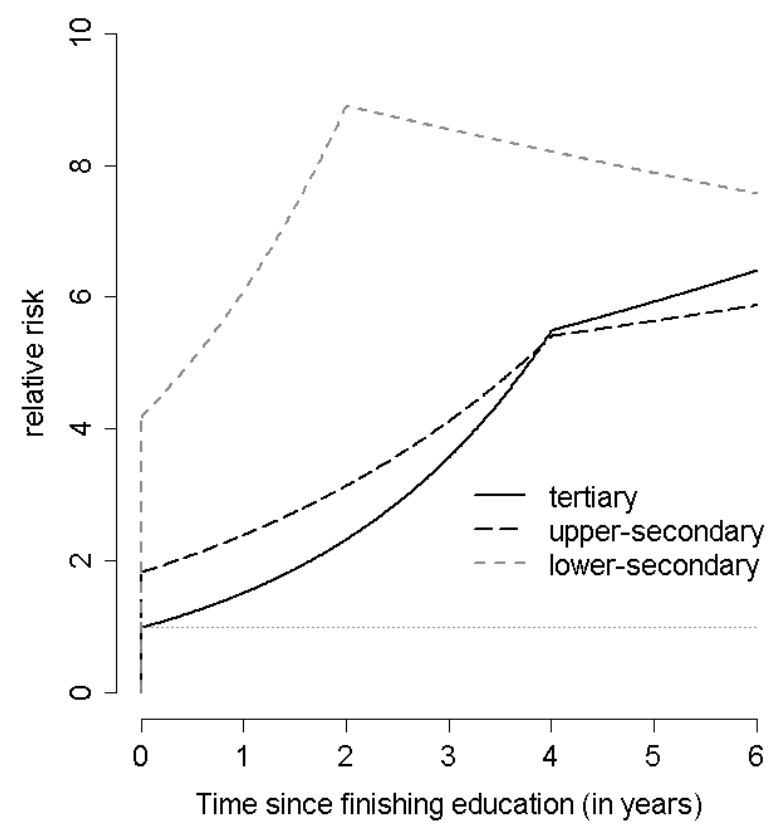

b) Poland

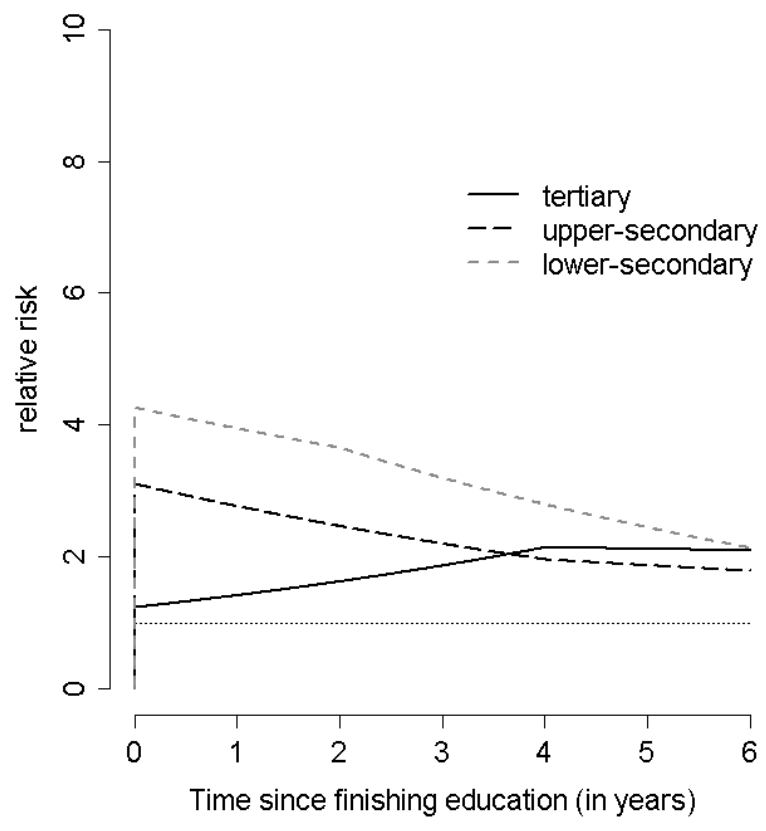

Note: The results come from the model as presented in Equation 1, i.e. standardized for woman's age, calendar period, women's social background, work experience, and non-employment experience.

Interestingly, women with upper-secondary education in Italy display a pattern similar to that of the tertiary educated group. By contrast, the timing of childbearing after graduation among Polish women with medium levels of education resembles that of the less-educated. We attribute this finding to the different occupational structures of upper-secondary educated women in the two countries. In Italy, these women find employment predominantly as technicians and associate professionals, followed by clerks (own elaboration on 2001 Italian 
Population Census). In Poland, they are most likely to be employed as service workers and shop and market sales workers (own elaboration on the 2006 Polish Labor Force Survey), which represent lower positions in the occupational hierarchy. This means that the uppersecondary educated in Italy have higher social status than their counterparts in Poland, and therefore might be more likely to display behaviors similar to those of the tertiary educated.

Figure 5 presents the effect of another element of human capital, namely work experience. It provides support for the hypothesis that those women who are at the beginning of their careers are less likely to have a child, preferring instead to first accumulate on-the-job skills. With the time, as the indirect costs of career interruption decline, the risk of birth increases.

\section{Figure 5. Effect of work experience on first birth risk}

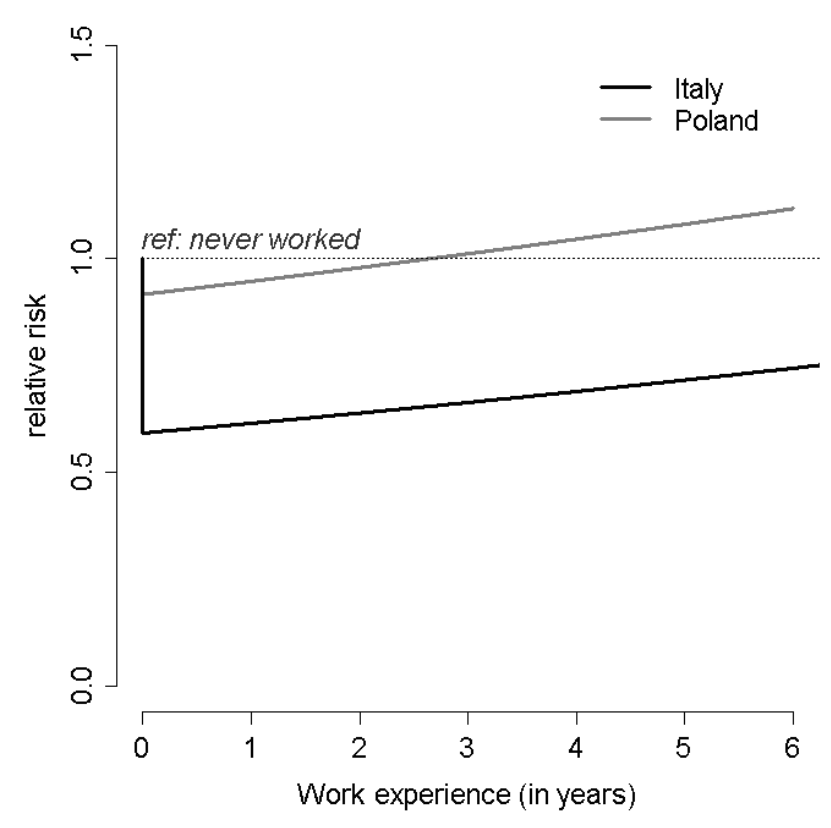

Note: The results come from the model as presented in Equation 1, i.e., standardized for a woman's age, calendar period, a woman's social background, time since leaving education, educational level, and nonemployment experience

The effect of work experience differs between the two analyzed countries, however. In Italy the risk of first birth is much lower at the entry into work, as well as over the whole period of employment, than in Poland. Furthermore, regardless of their work records, women in Italy have lower intensity of childbearing than those who have never worked. This is not true for Poland, where, after three years of accumulating work experience, women become 
more likely to become mothers than their counterparts who have never worked. These findings are in line with our expectations. Although both countries are characterized by strong incompatibilities between fertility and paid work, participation in the labor market seems to impede fertility much more strongly in Italy. By contrast, after a period of stabilization in the labor market, having a job in Poland seems to facilitate family formation.

To gain deeper insight into the impact of human capital on women's decision to become mothers, we interact work experience with the education level, as specified by Equation 2 (Section 5). This allows us to decompose the general pattern presented in Figure 5 by education. The results are presented in Figures $6 a-b$. The effects of work-experience are marked with a line, the filled symbols and a star represent the birth risks for women who have never worked whereas the blank symbols and a plus the risks for women who exited employment.

The risk of having a first child upon entry into employment declines for women with all education levels (apart from the low-educated in Poland), although the magnitude of this negative shift varies markedly according to the form of education. Moreover, it is evident that the intensity of first birth risk increases only for women with upper-secondary and tertiary education as they accumulate work experience. In particular, around a year after first starting employment, women with a university degree have a higher risk of having a first child (represented by 'a solid line') than tertiary educated women who have never worked ('a filled circle'). Thus, after disentangling the effect of work experience on first birth risk by education level, we find that having a job seems to facilitate entry into motherhood chiefly for tertiary educated women. This effect can be observed not only for Poland, as one could expect from Figure 5, but also for Italy.

Again, we find clear cross-country differences. The decline in first birth risk upon starting work is, for women with lower ('a dotted line') and upper-secondary ('a dashed line') levels of education, stronger in Italy than in Poland. It is notable that the two groups of women in the former country have continuously lower risks of giving birth than women with a corresponding education level who have never worked ('a filled triangle' and 'a star'). In Poland the intensity of childbearing among the upper-secondary educated declines only slightly upon starting a first job, and, after two years of human capital accumulation, it exceeds the first birth risk among women who had never worked. The fertility behavior of lower-secondary educated women does not seem to depend on whether they have a job the accumulated work experience. Overall, these findings illustrate that, in the case of secondary 
educated women, employment limits the transition to motherhood in Italy to a much larger extent than in Poland.

Figure 6. Effect of work-experience on first birth risk, by education

a) Italy

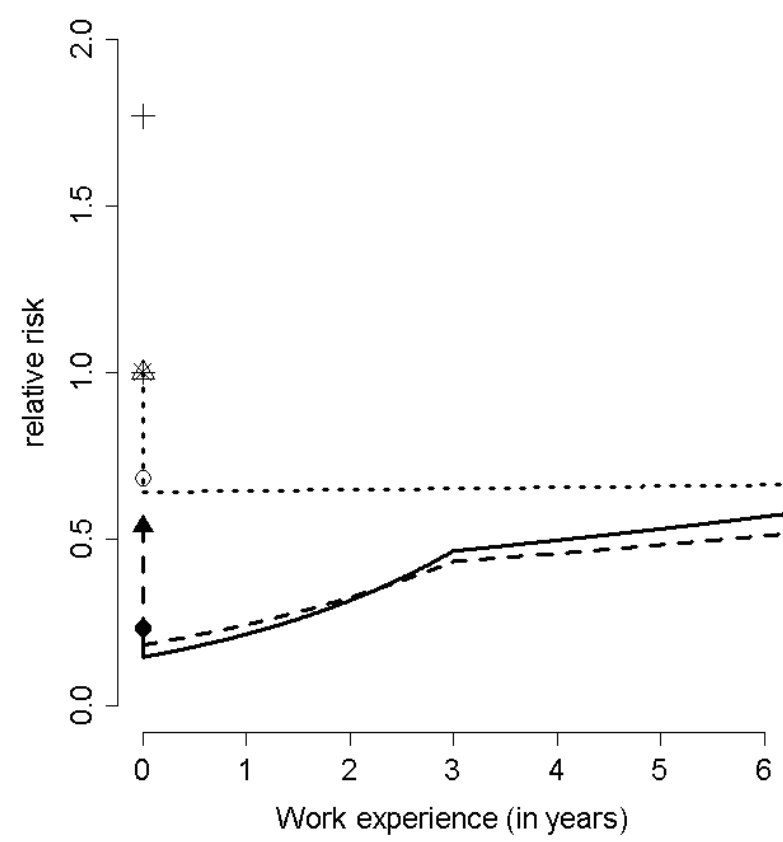

Effect of work-experience

- tertiary

- upper-secondary

.... lower-secondary
Never-worked

- tertiary

- upper-secondary

* lower-secondary b) Poland

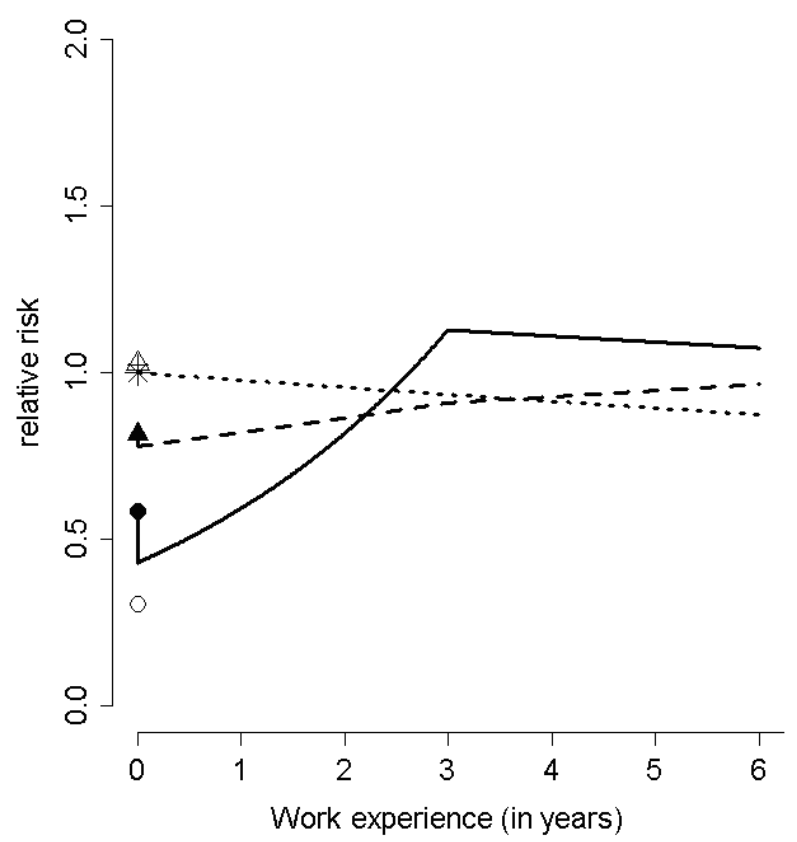

Effect of non-employment, after having had a job

o tertiary

$\triangle$ upper-secondary

+ lower-secondary

Note: The results come from the model as presented in Equation 2, i.e.. standardized for woman's age, calendar period, women's social background, and non-employment experience.

Among tertiary educated women, the conception risk upon first starting employment deteriorates more strongly in Poland than in Italy. Nevertheless, tertiary educated women in Poland display much larger increases in first birth intensity as they accumulate on-the-job skills than their counterparts in Italy. Three years after first entering employment, the risk of having a first child among Poles with university degrees exceeds even the risk faced by women with lower-secondary education who have never worked. The finding that Polish women with tertiary education who have a job will progress to their first child more quickly 
than Italian women is consistent with our expectations. Having tertiary education in Poland gives women much better employment prospects than in Italy, at least in terms of job stability.

In order to better understand the importance of employment for childbearing, we also investigated the impact of second and higher order non-employment spells on the transition to motherhood. In other words, we looked more closely at the fertility behaviors of women who had lost a job or terminated work voluntarily. Our results clearly suggest that exiting employment in Italy facilitates childbearing. Women who stopped working have a higher risk of first birth than the employed, irrespective of education level. In Poland, such an effect is observed only among the secondary educated ('a blank triangle' and 'a plus'), but it is much weaker in magnitude. Interestingly, women with university degrees who exited employment ('blank circle') are markedly less likely to give birth than those who have a job. This finding underlines the importance of employment for first childbearing among tertiary educated females in Poland.

\section{7 - Conclusions and implications}

This study aims to add to our understanding of the impact of women's human capital accumulation on the timing of first motherhood. We scrutinized the transition to motherhood in two societies characterized by strong conflicts between childrearing and market work, namely in Italy and Poland. These countries are similar in many respects, but also display important differences, which makes this comparison particularly informative.

We followed a common paradigm: we expected individuals to make their procreative choices intentionally, based on an evaluation, albeit imperfect, of the costs and benefits of reproduction. Our life-course study on the progression to having a first child provides explanations for differences in first birth timing among women with different levels of education and employment experience. The findings illustrate that women with higher education, as well as those who have just entered employment, are more likely to postpone having their first child until they accumulate more human capital and stabilize their position in the workplace.

The comparison between Italy and Poland provides new information that can facilitate our understanding of how the two country-specific settings filter the impact of human capital 
accumulation on the transition to first motherhood. Here we elaborate upon our results, opening the discussion by looking at the findings for low-educated women (10-11 years of schooling).

For this group we found no effect of work experience on first birth rate. This is likely because less-educated women probably do not attach any relevance to the accumulation of on-the-job skills, since they are likely to be less work-oriented, and tend to be clustered in the lower end of the occupational hierarchy. Nonetheless, entering paid work in Italy clearly impedes the transition to motherhood among low-educated women, while in Poland the first birth risk among the employed does not deviate from that of the non-employed.

By contrast, women with an upper-secondary degree (12-13 years of education) attribute higher value to the accumulation of work experience. This effect is more pronounced in Italy. We explain this finding by the fact that medium-educated women in Italy are in jobs which are higher in the occupational hierarchy, and which therefore require a higher degree of specialization than in Poland. Even after accumulating on-the-job skills, women in Italy are less likely to have a child than those who do not work, however. Exactly the opposite effect was found in Poland. This suggests that paid employment competes with motherhood to a much larger extent in Italy.

Women holding university degree display the strongest increment in first birth intensity, along with the accumulation of work experience. In both countries, they are more likely to conceive than women with corresponding educational levels who have never worked. This suggests that having a job is an important precondition for having a child among women who invested in obtaining a university degree. This effect is even stronger in Poland than in Italy. We attribute this finding to the fact that being tertiary educated gives women in Poland much better protection against job loss than in Italy. Consequently, it takes Italian women longer to find stability in the workplace, which results in greater fertility postponement. The impact of exiting employment after some accumulation of work experience further corroborates this view. In Italy, women with a university degree who have stopped working are more likely to have a first child than those who have a job, while in Poland, they are more likely to defer family formation. It can be argued that Polish women are, therefore, more oriented toward re-entering employment, which in our view represents a strong prerequisite for childbearing. In Italy, on the contrary, the uncertain labor market situation and low reentry opportunities may induce a loss of motivation, and increase the desire for motherhood.

All in all, our findings suggest that paid employment constitutes a clear barrier to childbearing in Italy, at least among low- and medium-educated women. In Poland, by 
contrast, employment functions as a precondition to childbearing, irrespective of the educational level. This is despite the fact that Polish women face equally pressing problems of incompatibility between fertility and paid work as their Italian counterparts. Such behavior can be explained by the existence of the strong income effect. The financial situation of households in Central and Eastern European countries is still much worse than in the West, and two incomes might therefore be necessary for family to be able to afford to have a child. The strong attachment of women to the labor force in Poland might also be due to the intergenerational transmission of the picture of a working mother that could have taken place during state socialism. Finally, one could also hypothesize that the perception of the housewives in Poland is much more negative than in Italy. This explanation requires further testing, however.

Other implications of our results are quite straightforward. Despite the fact that, for Italian women, work operates as a barrier, while for Polish women, it acts as a precondition to childbearing, we argue that policies aimed at easing the conflict between work and fertility are highly desired in both countries. These policies should aim at reducing the costs of early childbearing, allowing women to progress more quickly to motherhood. The continuous rise in the economic activity of Italian women reflects an increasing desire of women to participate in the labor force. Thus, if they anticipate having to leave the labor market in order to have a child, they will tend to postpone motherhood. The situation of the Polish mothersto-be might be even more difficult, since they cannot afford to drop out of employment.

The reconciliation policies may not be sufficient, however, if the barriers to the labor market entry remain high and employment contracts continue to be unstable. In such a situation, policies aimed at eliminating the uncertainty and unemployment risks among young people must be considered. What we need, therefore, is a level of flexibility that allows women to balance family and work, but does not destabilize the position of young women in the labor market.

Nevertheless, it is not only policies that can help in moderating the tempo effect. Overcoming the belief that children are "women's work" is even more important (Ranson, 1998). An adjustment in the couple-role set, manifested, for example, in an increased participation of men in the housework, should lead to a decline in the costs of children.

Finally, our results provide input and suggest possible directions for further research. We demonstrated that the marked rise in the timing at first motherhood is mainly a reaction to the increasing investment of women in their human capital in Italy and Poland. But this may not tell the whole story. Fertility postponement is also driven by other factors. Exploring the 
housing difficulties that Italian and Polish youth are facing might be a promising path of inquiry for future research. The rising desire for self-realization through a professional career, as well as in other spheres of life, including the growing demand for leisure time, the wish to invest more heavily in the quality of children, or even a change in the value placed on children, are a few of the factors that could also be responsible for the ongoing trend toward fertility ageing.

\section{Acknowledgments}

This study was conducted while Anna Matysiak and Daniele Vignoli were staying at the Population and Policy Laboratory, led by Gerda Neyer, at the Max Planck Institute for Demographic Research (MPIDR), Rostock, Germany. The paper benefited from discussions during a seminar presentation at the MPIDR, and has received helpful comments from Jan M. Hoem, Michaela Kreyenfeld, Monika Mynarska, Gerda Neyer, Brienna Perelli-Harris, and Marta Styrc. We are also grateful to Alessandra De Rose, Tomas Frejka, Jean-Paul Sardon, and Krzysztof Tymicki for having provided us with most of the demographic data used in Section 3.2 . 


\section{References:}

Adserà, A. (2005). Vanishing children: From high unemployment to low fertility in developed countries. American Economic Review, 95(2), 189-193.

Billari, C. F., Liefbroer, A. C., \& Philipov, D. (2006). The Postponement of Childbearing in Europe: Driving Forces and Implications, Vienna Yearbook of Population Research 2006, 1-17

Blossfed, H-P. \& Huinink J. (1991). Human Capital Investments or Norms of Role Transition? How Women's Schooling and Career Affect the Process of Family Formation. American Journal of Sociology, 97(1), 143-168.

Caltabiano M., Castiglioni M., \& Rosina A. (2007). Italian fertility: Is a recovery under way?, paper presented at the annual conference of the Population Association of America, New York, Usa, 29-31 March 2007.

Cigno, A., \& Ermisch J. (1989). A Microeconomic Analysis of the Timing of Births. European Economic Review 33, 737-60.

Dalla Zuanna, G. (2004). Few children in strong families. Values and low fertility in Italy. Genus, LX(1), Special edition on Italian Low Fertility between Economic Constraints and Changes of Values, 39-70.

Dalla Zuanna, G \& Micheli, G. A. (2004). Introduction - New perspectives in interpreting contemporary family and reproductive behaviour of Mediterranean Europe. In: G. Dalla Zuanna\& G. A. Micheli, (Eds.). Strong family and low fertility: a paradox? New perspectives in interpreting contemporary family and reproductive behaviour (pp. 7-21). Series: European Studies of Population, 14. Springer.

De Rose, A., Racioppi, F. \& Zanatta, A. L. (2008). Italy: Delayed adaptation of social institutions to changes in family behaviour. Demographic Research, Special Collection 7, 19:665-704.

Ermisch, J. F. (1989). Purchased Child Care, Optimal Family Size and Mother's Employment. Journal of Population Economics, 2, 79-102.

Esping-Andersen, G. (1999). Social foundations of postindustrial economies. Oxford: Oxford University Press.

Eurostat New Cronos Database, http://www. ec.europa.eu/eurostat/, data retrieved January 2009.

Frejka, T. \& Sardon, J.-P. (2006). First birth trends in developed countries: Persisting parenthood postponement. Demographic Research, 15: 6, 147-180.

Frejka, T., Sobotka, T., Hoem, J. M., \& Toulemon, L. (eds.). (2008). Childbearing Trends and Policies in Europe. Demographic Research, Special Collection 7.

Frejka, T. (2008). Overview Chapter 5: Determinants of family formation and childbearing during the societal transition in Central and Eastern Europe. Demographic Research, Special Collection 7, 139-170.

Gustafsson, S. S. (2001). Optimal age at motherhood. Theoretical and empirical considerations on postponement of maternity in Europe. Journal of Population Economics, 14, 225-247.

Gustafsson, S. S., \& Wetzels, C. (2000). Optimal age for first birth: Germany, Great Britain, the Netherlands and Sweden. In S. S. Gustafsson \& D. E. Meulders (Eds.), Gender and 
the labour market. Econometric evidence on obstacles in achieving gender equality (pp. 188-209). Palgrave Macmillan.

Hantrais, L. (2005). Living as a family in Europe. In L. Hantrais, D. Philipov \& F. C. Billari (Eds.), Policy Implications of Changing Family Formation (pp.117-181). Strasburg: Council of Europe Publishing.

Happel, S.K., J.K. Hill, \& S.A. Low. 1984. An Economic Analysis of the Timing of Childbirth. Population Studies 38(2), 299-311.

Hotz, V. J., Klerman, J. A., \& Willis R. J. (1997). The Economics of Fertility in Developed Countries. Handbook of Population and Family Economics, 1A, 275-347.

International Labour Organization (ILO) Laborsta Database - http://laborsta.ilo.org/, data retrieved January 2009

Inglehart, R. (1990). Cultural Shift in Advanced Industrial Society. Princeton: Princeton University Press.

Kantorová, V. (2004). Education and Entry into Motherhood: The Czech Republic during State Socialism and the Transition Period (1970-1997). Demographic Research Special Collection 3, 243-74.

Kertzer, D. K., White, M. Bernardi, L., \& Gabrielli, G. (2008). Italy's path to very low fertility: the adequacy of economic and Second Demographic Transition theories. European Journal of Population (on-line first).

Kotowska, I. E. (1999). Drugie przejście demograficzne i jego uwarunkowania (Second demographic transition and its conditions). In I. E. Kotowska (Ed.), Przemiany demograficzne $w$ Polsce $w$ kontekście drugiego przejścia demograficznego (Demographic changes in Poland in the context of the second demographic transition) (pp. 11-33). Warsaw: Warsaw School of Economics Publishing.

Kotowska, I.E. 2005. Europa wobec przeobrażeń rodziny. Czy potrzebna jest europejska stratega prorodzinna? (Europe towards family changes. Do we need an European family strategy?). In: Mariusz J. Radło (ed.). Polska wobec redefinicji Strategii Lizbońskiej (Poland toward a redefinition of the Lisbon Strategy). Warsaw and Gdańsk: Green Paper of the Polish Forum of Lisbon Strategy, pp. 223-241.

Kotowska, I. E. \& Sztanderska, U. (2007). Zmiany demograficzne a zmiany na rynku pracy w Polsce (Population changes and labour market developments in Poland). In I. E. Kotowska, U. Sztanderska, \& I. Wóycicka (Eds.). Aktywność zawodowa i edukacyjna a obowiazki rodzinne $w$ Polsce $w$ świetle badań empirycznych (Economic and educational activity versus family obligations in Poland) (pp. 13-46). Warsaw: Scholar Publishing.

Kotowska, I., Józwiak, J., Matysiak, A., \& Baranowska, A. (2008). Poland: Fertility decline as a response to profound societal and labour market changes?. Demographic Research, Special Collection 7, $795-854$.

Kravdal, O. 1994. The Importance of Economic Activity, Economic Potential and Economic Resources for the Timing of First Births in Norway. Population Studies 48, 249-267.

Lappegård, T. \& Rønsen, M. (2005). The multifaceted impact of education on entry into motherhood. European Journal of Population, 21, 31-49.

Lesthaeghe, R. (1992). The second demographic transition in Western Countries. In M. K. Oppenheim \& A. Jensen (Eds.), Gender and family change (pp. 17-62). Oxford: Clarendon Press. 
Lillard, L.A. (1993). Simultaneous equations for hazards. Marriage duration and fertility timing. Journal of Econometrics, 56, 189-217.

Livi Bacci, M. (2001), Too few children and too much family. Daedalus, 130(3),139-156.

Lück, D. \& Hofäcker, D. (2003). Rejection and Acceptance of the Male Breadwinner Model: Which Preferences do Women Have under Which Circumstances? Globalife Working Paper, 60, University of Bamberg.

Mariański, J. (2007). New dimensions of religiosity differentials in Poland. In A. Kojder (Ed.), One Poland? Old and New Social Differences (pp. 177-204). Cracow: Polish Academy of Sciences.

Matysiak, A. (2007). Indywidualne przesłanki zwiększenia aktywności ekonomicznej ludności (Individual prerequisities for increasing economic activity). In I.E. Kotowska, U. Sztanderska \& I. Wóycicka (Eds.). Aktywność zawodowa i edukacyjna a obowiazki rodzinne $w$ Polsce $w$ świetle badań empirycznych (Economic and educational activity versus family obligations in Poland) (pp. 383-403). Warsaw: Scholar Publishing,.

Matysiak, A. (2008). On the interdependencies between fertility and women's labour force participation. Doctoral Thesis. Institute of Statistics and Demography. Warsaw: Warsaw School of Economics.

Matysiak, A. \& Steinmetz, S. (2008). Finding Their Way? Female employment Patterns in West Germany, East Germany, and Poland. European Sociological Review 24(3), 331345.

Matysiak, A., \& Vignoli, D. (2008). Fertility and Women's Employment: A Meta-Analysis. European Journal of Population, 24(4), 363-384.

Matysiak, A. \& Vignoli, D. (2009). Family and Work Re-Conciliation: A New Approach to an Old Problem. In: M. Kuhn \& C. Ochsen (Eds.), Labour Markets and Demographic Change (pp. 235-254). Wiesbaden: VS Verlag.

Mencarini, L. \& Tanturri, M. L. (2006). High Fertility or Childlessness: Micro-Level Determinants of Reproductive Behaviour in Europe. Population, 4, 389-416.

McDonald, P. (2000). Gender equity, social institutions and the future of fertility. Journal of Population Research, 17(1), 1-16.

McDonald, P. (2001). Work-family policies are the right approach to the prevention of low fertility. People and Place, 9(3), 17-27.

Mills, M., \& Blossfeld, H.-P. (2005). Globalization, Uncertainty and the Early Life Course: A Theoretical Framework. In Blossfeld H-P., E. Klizing, M. Mills \& K. Kurz (Eds.), Globalization, Uncertainty and Youth in Society (pp. 1-24). London and New York: Routledge.

Mills, M., Blossfeld, H.-P. \& Klizing, E. (2005). Becaming an aduld in uncertain times: a 14country comparison of the losers of globalization. In Blossfeld H-P., E. Klizing, M. Mills \& K. Kurz (Eds.), Globalization, Uncertainty and Youth in Society (pp. 423-443). London and New York: Routledge.

Muszyńska, M. (2007). Structural and cultural determinants of fertility in Europe. Warsaw: Warsaw School of Economics Publishing.

Neyer, G. (2003). Family policies and low fertility in Western Europe. MPIDR Working Paper WP 2003-021, Rostock. 
Nicoletti, C. \& Tanturri, M. L. (2008). Differences in Delaying Motherhood Across European Countries: Empirical Evidence from the ECHP. European Journal of Population, 24, 157-183.

Philipov, D. (2008). Family-related Gender Attitudes. In: C. Höhn, D. Avramov \& I.E. Kotowska, (Eds.), People, Population Change and Policies: Lessons from the Population Policy Acceptance Study Vol. 1 (pp. 153-174), 2: Demographic Knowledge Gender - Ageing. Springer.

Rai, R., R. Naderi \& P. Schimany. (2008). Who should take care for them? Expectations placed on the welfare state and their influence on attitudes towards care for the elderly. In Ch. Höhn, D. Avramov \& I. E. Kotowska (Eds.), People, Population Change and Policies: Lessons from the Population Policy Acceptance Study Vol. 2 (pp. 51-73). European Studies of Population, Springer.

Ranson, G. (1998). Educaton, Work and Family Decision Making: Finding the "Right Time" to Have a Baby. CRSA/RCSA.

Rindfuss, R. R., Guzzo, K., \& Morgan, S. P. (2003). The changing institutional context of low fertility. Population Research and Policy Review, 22, 411-438.

Rosina, A., \& Fraboni R. (2004). Is marriage losing its centrality in Italy? Demographic Research, 11(6), 149-172.

Salvini, S. \& Ferro, I. (2007). Young workers and flexibility of the labour market: what family strategies? Department of Statistics “G. Parenti" Working Paper 2007/13, University of Florence.

Siemieńska, R. (1997). Wartości i postawy warunkujące obecność kobiet na rynku pracy (Values and attitudes determining women's labour supply). In: Siemieńska R. (ed.), Wokót problemów zawodowego równouprawnienia kobiet $i$ mężczyzn (On the gender equality in the labour market). Warsaw: Institute of Philosophy and Sociology, Polish Academy of Sciences.

Sztanderska, U. (2005). Aktywność zawodowa kobiet w Polsce. Jakie szanse? Jakie rezultaty? (Labour force participation of women in Poland? What opportunties? What outcomes?) In: Szanse na wzrost dzietności - jaka polityka rodzinna? (Possibilities of increasing fertility - which family policies?). Blue Paper of the Polish Forum of Lisbon Strategy. Warsaw-Gdansk: Gdansk Institute on Market Economics, pp. 43-63.

Stankuniene, V., \& Maslauskaite, E. (2008). Family transformations in the post-communist countries: Attitudes toward changes and the ideational shift, In Ch. Höhn, D. Avramov \& I. E. Kotowska (Eds.), People, Population Change and Policies: Lessons from the Population Policy Acceptance Study Vol. 1 (pp. 113-137). European Studies of Population, Springer.

Sobotka, T. (2004). Postponement of Childbearing and Low Fertility in Europe. Population Studies, Dutch University Press.

Surkin, J., \& Lesthaeghe, R. (2004), Value Orientations and the Second Demographic Transition (SDT) in Northern, Western and Southern Europe: An Update. Demographic Research Special Collection 3.

Taniguchi, H. The Timing of Childbearing and Women's Wages. Journal of Marriage and the Family, 61(4), 1008-1019.

Vignoli, D. (2008). Work and fertility. Employment and reproductive careers among Italian couples. Doctoral Thesis. Rome: La Sapienza, University of Rome. 
Vignoli, D., \& Ferro, I. (2009). Rising marital disruption in Italy and its correlates. Demographic Research, 20, 11-36.

Walker, J.R. (1995). The effect of public policies on recent Swedish fertility behaviour. Journal of Population Economics, 8, 223-251.

Zabel C. (2006). Employment Experience and First Birth in Great Britain. Max Planck Institute for Demographic Research Working Paper 2006-029. 
APPENDIX - Stepwise model presentation for Italy and Poland.

Italy - Results from Equation 1.

\begin{tabular}{|c|c|c|c|c|c|c|c|c|c|c|}
\hline & Model 1 & & Model 2 & & Model 3 & & Model 4 & & Model 5 & \\
\hline constant & $\begin{array}{l}-5.90 \\
(0.18)\end{array}$ & 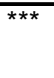 & $\begin{array}{l}-7.03 \\
(0.22)\end{array}$ & $\star \star \star$ & $\begin{array}{l}-7.63 \\
(0.23)\end{array}$ & 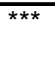 & $\begin{array}{l}-7.93 \\
(0.29)\end{array}$ & $\star \star \star$ & $\begin{array}{l}-7.95 \\
(0.29)\end{array}$ & 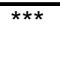 \\
\hline \multicolumn{11}{|l|}{ Age } \\
\hline 15-20 (slope) & $\begin{array}{c}0.44 \\
(0.04)\end{array}$ & 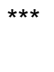 & $\begin{array}{c}0.51 \\
(0.04)\end{array}$ & $\star \star \star$ & $\begin{array}{c}0.51 \\
(0.04)\end{array}$ & $\star \star \star$ & $\begin{array}{c}0.40 \\
(0.05)\end{array}$ & 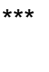 & $\begin{array}{c}0.41 \\
(0.05)\end{array}$ & $\star \star \star$ \\
\hline 20-24 (slope) & $\begin{array}{c}0.14 \\
(0.02)\end{array}$ & 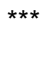 & $\begin{array}{c}0.22 \\
(0.03)\end{array}$ & 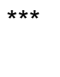 & $\begin{array}{c}0.22 \\
(0.03)\end{array}$ & $\star \star \star ~$ & $\begin{array}{c}0.18 \\
(0.03)\end{array}$ & *** & $\begin{array}{c}0.18 \\
(0.03)\end{array}$ & 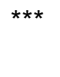 \\
\hline 24-28 (slope) & $\begin{array}{c}0.15 \\
(0.02)\end{array}$ & *** & $\begin{array}{c}0.19 \\
(0.02)\end{array}$ & $\star \star \star ~$ & $\begin{array}{c}0.19 \\
(0.02)\end{array}$ & $\star \star \star$ & $\begin{array}{c}0.16 \\
(0.03)\end{array}$ & *** & $\begin{array}{c}0.15 \\
(0.03)\end{array}$ & $\star \star \star ~$ \\
\hline 28-33 (slope) & $\begin{array}{c}0.05 \\
(0.03)\end{array}$ & * & $\begin{array}{c}0.09 \\
(0.03)\end{array}$ & 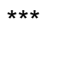 & $\begin{array}{c}0.08 \\
(0.03)\end{array}$ & $\star \star \star ~$ & $\begin{array}{c}0.03 \\
(0.03)\end{array}$ & & $\begin{array}{c}0.02 \\
(0.03)\end{array}$ & \\
\hline 32-36 (slope) & $\begin{array}{l}-0.15 \\
(0.07)\end{array}$ & ** & $\begin{array}{c}-0.11 \\
(0.07)\end{array}$ & & $\begin{array}{l}-0.11 \\
(0.07)\end{array}$ & & $\begin{array}{l}-0.16 \\
(0.07)\end{array}$ & ** & $\begin{array}{l}-0.17 \\
(0.07)\end{array}$ & $\star \star *$ \\
\hline \multicolumn{11}{|l|}{ Calendar period } \\
\hline 1982-2003 (slope) & & & $\begin{array}{l}-0.07 \\
(0.01)\end{array}$ & $\star \star \star$ & $\begin{array}{l}-0.06 \\
(0.01)\end{array}$ & $\star \star \star$ & $\begin{array}{l}-0.04 \\
(0.01)\end{array}$ & 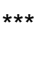 & $\begin{array}{l}-0.04 \\
(0.01)\end{array}$ & $\star \star \star \star ~$ \\
\hline \multicolumn{11}{|l|}{ Parent's education } \\
\hline Father educ. - low (ref: high) & & & & & $\begin{array}{c}0.45 \\
(0.09)\end{array}$ & $\star \star \star ~$ & $\begin{array}{c}0.18 \\
(0.09)\end{array}$ & ** & $\begin{array}{c}0.18 \\
(0.09)\end{array}$ & * \\
\hline Mother educ. - low (ref: high) & & & & & $\begin{array}{c}0.33 \\
(0.10)\end{array}$ & 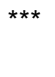 & $\begin{array}{c}0.04 \\
(0.10)\end{array}$ & & $\begin{array}{c}0.03 \\
(0.10)\end{array}$ & \\
\hline \multicolumn{11}{|l|}{$\begin{array}{l}\text { Years since leaving education } \\
\text { Tertiary }\end{array}$} \\
\hline $\begin{array}{l}\text { Tertiary } \\
\text { Exiting education (shift) }\end{array}$ & & & & & & & $\begin{array}{l}-0.08 \\
(0.34)\end{array}$ & & $\begin{array}{c}0.01 \\
(0.34)\end{array}$ & \\
\hline $0-4$ years (slope) & & & & & & & $\begin{array}{c}0.42 \\
(0.10)\end{array}$ & *** & $\begin{array}{l}0.45 \\
(0.10)\end{array}$ & 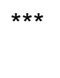 \\
\hline $4+$ years (slope) & & & & & & & $\begin{array}{c}0.08 \\
(0.05)\end{array}$ & * & $\begin{array}{c}0.08 \\
(0.05)\end{array}$ & \\
\hline \multicolumn{11}{|l|}{ Upper-secondary } \\
\hline Exiting education (shift) & & & & & & & $\begin{array}{r}1.11 \\
(0.12)\end{array}$ & *** & $\begin{array}{l}1.13 \\
(0.12)\end{array}$ & $\star \star \star$ \\
\hline 0-4 years (slope) & & & & & & & $\begin{array}{l}-0.10 \\
(0.04)\end{array}$ & ** & $\begin{array}{l}-0.12 \\
(0.04)\end{array}$ & 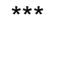 \\
\hline $4+$ years (slope) & & & & & & & $\begin{array}{r}-0.04 \\
(0.04)\end{array}$ & & $\begin{array}{l}-0.05 \\
(0.04)\end{array}$ & \\
\hline \multicolumn{11}{|l|}{ Lower-secondary } \\
\hline Exiting education (shift) & & & & & & & $\begin{array}{r}1.42 \\
(0.16)\end{array}$ & *** & $\begin{array}{l}1.45 \\
(0.17)\end{array}$ & $\star \star \star *$ \\
\hline $0-2$ years (slope) & & & & & & & $\begin{array}{l}-0.05 \\
(0.10)\end{array}$ & & $\begin{array}{l}-0.08 \\
(0.10)\end{array}$ & \\
\hline $2+$ years (slope) & & & & & & & $\begin{array}{r}-0.12 \\
(0.02)\end{array}$ & *** & $\begin{array}{l}-0.13 \\
(0.02)\end{array}$ & $\star \star \star ~$ \\
\hline \multicolumn{11}{|l|}{ Work experience } \\
\hline Employment entry (shift) & & & & & & & & & $\begin{array}{l}-0.52 \\
(0.08)\end{array}$ & $\star \star \star$ \\
\hline Work experience (slope) & & & & & & & & & $\begin{array}{c}0.04 \\
(0.01)\end{array}$ & $\star \star \star$ \\
\hline $\begin{array}{l}\text { Non-employment of second o } \\
\text { order (ref: never worked) }\end{array}$ & & & & & & & & & $\begin{array}{c}0.57 \\
(0.08)\end{array}$ & 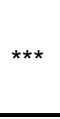 \\
\hline In-L & -17537 & & -17496 & & -17440 & & -17130 & & -17061 & \\
\hline
\end{tabular}


Poland - Results from Equation 1.

\begin{tabular}{|c|c|c|c|c|c|}
\hline & Model 1 & Model 2 & Model 3 & Model 4 & Model 5 \\
\hline constant & $\begin{array}{l}-5.26 \\
(0.15)\end{array}$ & $\begin{array}{l}-6.06^{\star \star \star} \\
(0.17)\end{array}$ & $\begin{array}{l}-6.37^{\star \star \star} \\
(0.18)\end{array}$ & $\begin{array}{l}{ }^{-5.98} \\
(0.19)\end{array}$ & 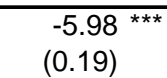 \\
\hline \multicolumn{6}{|l|}{ Age } \\
\hline 15-20 (slope) & $\begin{array}{l}0.63 \text { *** } \\
(0.03)\end{array}$ & $\begin{array}{l}0.69 \text { *** } \\
(0.03)\end{array}$ & $\begin{array}{l}0.69 \text { *** } \\
(0.03)\end{array}$ & $\begin{array}{l}0.52 \text { *** } \\
(0.04)\end{array}$ & $\begin{array}{l}0.52 \text { *** } \\
(0.04)\end{array}$ \\
\hline 20-24 (slope) & $\begin{array}{r}0.02 \\
(0.02)\end{array}$ & $\begin{array}{l}0.09 \\
(0.02)\end{array}$ & $\begin{array}{l}0.09 \\
(0.02)\end{array}$ & $\begin{array}{l}0.14 \\
(0.03)\end{array}$ & $\begin{array}{l}0.14 \\
(0.03)\end{array}$ \\
\hline 24-28 (slope) & $\begin{array}{r}0.03 \\
(0.03)\end{array}$ & $\begin{array}{c}0.06 \text { ** } \\
(0.03)\end{array}$ & $\begin{array}{c}0.06 \text { * } \\
(0.03)\end{array}$ & $\begin{array}{r}0.04 \\
(0.04)\end{array}$ & $\begin{array}{r}0.03 \\
(0.04)\end{array}$ \\
\hline 28-33 (slope) & $\begin{array}{l}-0.08 \\
(0.06)\end{array}$ & $\begin{array}{l}-0.06 \\
(0.06)\end{array}$ & $\begin{array}{l}-0.09 \\
(0.06)\end{array}$ & $\begin{array}{l}-0.04 \\
(0.06)\end{array}$ & $\begin{array}{l}-0.05 \\
(0.06)\end{array}$ \\
\hline 32-36 (slope) & $\begin{array}{l}-0.46 \text { ** } \\
(0.21)\end{array}$ & $\begin{array}{l}-0.42 \text { ** } \\
(0.21)\end{array}$ & $\begin{array}{l}-0.45 \\
(0.21)\end{array}$ & $\begin{array}{l}-0.37 \text { * } \\
(0.21)\end{array}$ & $\begin{array}{l}-0.38 \text { * } \\
(0.21)\end{array}$ \\
\hline \multicolumn{6}{|l|}{ Calendar period } \\
\hline 1986-2006 (slope) & & $\begin{array}{l}-0.07 \\
(0.08)\end{array}$ & $\begin{array}{l}-0.05 \text { *** } \\
(0.08)\end{array}$ & $\begin{array}{l}-0.04^{* * *} \\
(0.08)\end{array}$ & $\begin{array}{l}-0.04 \text { *** } \\
(0.08)\end{array}$ \\
\hline \multicolumn{6}{|l|}{ Parent's education } \\
\hline Father educ. - low (ref: high) & & & $\begin{array}{l}0.31 \text { *** } \\
(0.07)\end{array}$ & $\begin{array}{l}0.20 \\
(0.08)\end{array}$ & $\begin{array}{l}0.20 \\
(0.08)\end{array}$ \\
\hline Mother educ. - low (ref: high) & & & $\begin{array}{l}0.34 \text { *** } \\
(0.07)\end{array}$ & $\begin{array}{c}0.14 \text { * } \\
(0.07)\end{array}$ & $\begin{array}{c}0.13 \\
(0.07)\end{array}$ \\
\hline \multicolumn{5}{|l|}{ Years since leaving education } & \\
\hline Exiting education (shift) & & & & $\begin{array}{r}0.19 \\
(0.17)\end{array}$ & $\begin{array}{r}0.21 \\
(0.17)\end{array}$ \\
\hline $0-4$ years (slope) & & & & $\begin{array}{l}0.15 \text { ** } \\
(0.07)\end{array}$ & $\begin{array}{l}0.14 \\
(0.07)\end{array}$ \\
\hline $4+$ years (slope) & & & & $\begin{array}{r}0.00 \\
(0.09)\end{array}$ & $\begin{array}{l}-0.01 \\
(0.09)\end{array}$ \\
\hline \multicolumn{6}{|l|}{ Upper-secondary } \\
\hline Exiting education (shift) & & & & $\begin{array}{l}1.11 \text { *** } \\
(0.12)\end{array}$ & $\begin{array}{l}1.13^{* \star *} \\
(0.12)\end{array}$ \\
\hline $0-4$ years (slope) & & & & $\begin{array}{l}-0.10 \\
(0.04)\end{array}$ & $\begin{array}{l}-0.12 \text { *** } \\
(0.04)\end{array}$ \\
\hline $4+$ years (slope) & & & & $\begin{array}{r}-0.04 \\
(0.04)\end{array}$ & $\begin{array}{r}-0.05 \\
(0.04)\end{array}$ \\
\hline \multicolumn{6}{|l|}{ Lower-secondary } \\
\hline Exiting education (shift) & & & & $\begin{array}{l}1.42 \text { *** } \\
(0.17)\end{array}$ & $\begin{array}{l}1.45^{\text {*** }} \\
(0.17)\end{array}$ \\
\hline 0-2 years (slope) & & & & $\begin{array}{l}-0.05 \\
(0.10)\end{array}$ & $\begin{array}{l}-0.08 \\
(0.10)\end{array}$ \\
\hline $2+$ years (slope) & & & & $\begin{array}{l}-0.12 \text { *** } \\
(0.02)\end{array}$ & $\begin{array}{l}-0.13^{\text {*** }} \\
(0.022)\end{array}$ \\
\hline \multicolumn{6}{|l|}{ Work experience } \\
\hline Employment entry (shift) & & & & & $\begin{array}{r}-0.09 \\
(0.08)\end{array}$ \\
\hline Work experience (slope) & & & & & $\begin{array}{l}0.03 \text { ** } \\
(0.016)\end{array}$ \\
\hline $\begin{array}{l}\text { Non-employment of second or higher } \\
\text { order (ref: never worked) }\end{array}$ & & & & & 0.16 \\
\hline & & & & & $(0.11)$ \\
\hline
\end{tabular}

Note: Significance level of coefficients: $*=10 \% ; * *=5 \% ; * * *=1 \%$. Standard errors are presented in parentheses. Those estimates presented in form of slopes show how the hazard increases or decreases over a certain time period. 
Italy and Poland - Results from Equation 2.

\begin{tabular}{|c|c|c|c|c|}
\hline & Italy & & Poland & \\
\hline constant & $\begin{array}{l}-5.68 \\
(0.24)\end{array}$ & 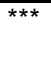 & $\begin{array}{c}-4.88 \\
(0.21)\end{array}$ & 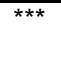 \\
\hline \multicolumn{5}{|l|}{ Age } \\
\hline 15-20 (slope) & $\begin{array}{c}0.40 \\
(0.04)\end{array}$ & *** & $\begin{array}{c}0.55 \\
(0.04)\end{array}$ & $* * *$ \\
\hline 20-24 (slope) & $\begin{array}{c}0.20 \\
(0.03)\end{array}$ & *** & $\begin{array}{l}0.053 \\
(0.03)\end{array}$ & ** \\
\hline 24-28 (slope) & $\begin{array}{c}0.15 \\
(0.02)\end{array}$ & *** & $\begin{array}{c}-0.03 \\
(0.03)\end{array}$ & \\
\hline 28-33 (slope) & $\begin{array}{c}0.03 \\
(0.03)\end{array}$ & & $\begin{array}{l}-0.07 \\
(0.06)\end{array}$ & \\
\hline 32-36 (slope) & $\begin{array}{l}-0.15 \\
(0.07)\end{array}$ & ** & $\begin{array}{l}-0.45 \\
(0.21)\end{array}$ & ** \\
\hline \multicolumn{5}{|l|}{ Calendar period } \\
\hline 1982-2003 IT; 1986-2006 PL (slope) & $\begin{array}{l}-0.05 \\
(0.01)\end{array}$ & *** & $\begin{array}{c}-0.04 \\
(0.01)\end{array}$ & $\star \star \star ~$ \\
\hline \multicolumn{5}{|l|}{ Parent's education } \\
\hline Father educ. - low (ref: high) & $\begin{array}{c}0.16 \\
(0.09)\end{array}$ & * & $\begin{array}{c}0.18 \\
(0.08)\end{array}$ & ** \\
\hline Mother educ. - low (ref: high) & $\begin{array}{c}0.01 \\
(0.10)\end{array}$ & & $\begin{array}{c}0.14 \\
(0.07)\end{array}$ & * \\
\hline \multicolumn{5}{|l|}{ Work-experience * education } \\
\hline Entry in first employment (shift) & $\begin{array}{l}-1.92 \\
(0.41)\end{array}$ & *** & $\begin{array}{c}-0.85 \\
(0.26)\end{array}$ & $\star \star \star *$ \\
\hline Work experience $0-3$ years (slope) & $\begin{array}{c}0.39 \\
(0.16)\end{array}$ & ** & $\begin{array}{c}0.32 \\
(0.10)\end{array}$ & $\star \star \star \star ~$ \\
\hline Work experience $3+$ years (slope) & $\begin{array}{c}0.07 \\
(0.04)\end{array}$ & & $\begin{array}{l}-0.02 \\
(0.04)\end{array}$ & \\
\hline \multicolumn{5}{|l|}{ Upper-secondary } \\
\hline Entry in first employment (shift) & $\begin{array}{l}-1.70 \\
(0.24)\end{array}$ & $* * *$ & $\begin{array}{l}-0.25 \\
(0.16)\end{array}$ & \\
\hline Work experience $0-3$ years (slope) & $\begin{array}{c}0.29 \\
(0.09)\end{array}$ & *** & $\begin{array}{c}0.05 \\
(0.07)\end{array}$ & \\
\hline Work experience $3+$ years (slope) & $\begin{array}{c}0.05 \\
(0.02)\end{array}$ & *** & $\begin{array}{c}0.02 \\
(0.03)\end{array}$ & \\
\hline \multicolumn{5}{|l|}{ Lower-secondary } \\
\hline Entry in first employment (shift) & $\begin{array}{l}-0.44 \\
(0.11)\end{array}$ & $* * *$ & $\begin{array}{c}0.00 \\
(0.12)\end{array}$ & \\
\hline Work experience (slope) & $\begin{array}{c}0.01 \\
(0.01)\end{array}$ & & $\begin{array}{c}-0.02 \\
(0.02)\end{array}$ & \\
\hline
\end{tabular}

Non-employment of second or higher order * education (ref=never-worked with lower-secondary)

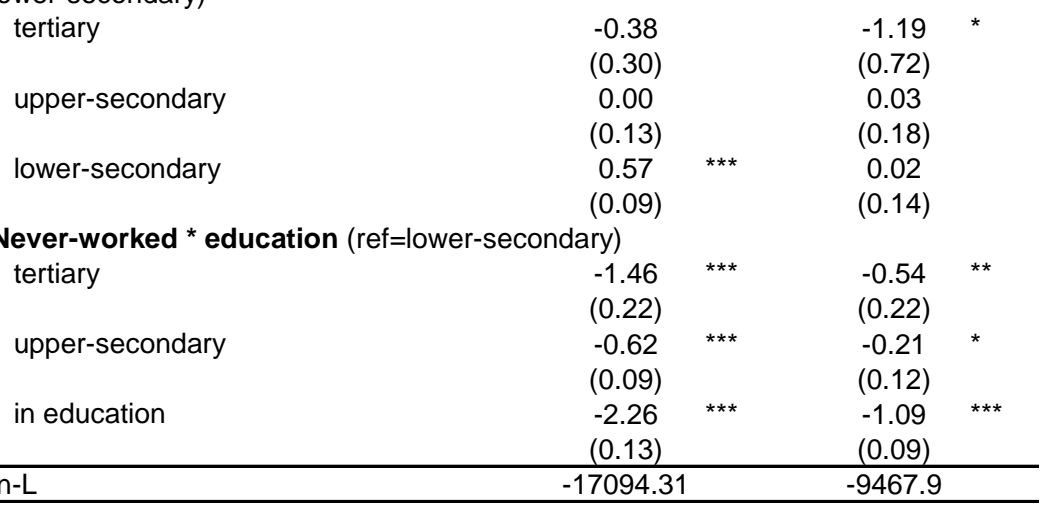

Note: Significance level of coefficients: $*=10 \% ; * *=5 \% ; * * *=1 \%$. Standard errors are presented in parentheses. Those estimates presented in form of slopes show how the hazard increases or decreases over a certain time period. 